\title{
TRATAMENTO ESTATÍSTICO E ANÁLISE DOS DADOS DE COBRE E OURO DA JAZIDA DE COBRE DE CHAPADA, GO
}

\author{
J.K.Yamamoto
}

Os resultados do tratamento estatístico e análise das informações de litologia e determinações geoquímicas para cobre e ouro da Jazida de Cobre de Chapada são apresentados neste trabalho. Tais estudos foram feitos sob a ótica de uma análise exploratória com o objetivo de conhecer e caracterizar as populações dos dados em consideração para fins de avaliação de reservas. Assim, foram estudadas possíveis correlações de teores de cobre e ouro com suas respectivas litologias, descritas macroscopicamente ao longo de $15.000 \mathrm{~m}$ de testemunhos de sondagem, com o objetivo de verificar o comportamento dos teores de cobre e ouro em relação à rocha hospedeira, bem como em relação a possíveis efeitos da presença de quartzo, cianita e feldspatização e, conseqüentemente, para o melhor conhecimento da distribuição da mineralização nas rochas de Chapada. Além da análise dos dados de litologia, foi realizada também a análise estatística dos teores de cobre e ouro, antes e depois da composição das amostras para a altura das bancadas. A composição de amostras tem como objetivo obter amostras representativas de uma unidade mineralógica particular ou unidade de mineração, que podem ser utilizadas, por meio de alguma função de extensão, para estimar o teor ou valor de um volume muito maior da mesma unidade. Para o caso em estudo, a composição de amostras foi feita para a altura das bancadas, pois a futura lavra poderia ser feita a céu aberto. O tratamento estatístico é feito então com o objetivo de caracterizar as distribuições de freqüências dos teores originais e compostos. A análise estatística dos dados originais foi feita para conhecer a população dos dados em estudo como : tipo e forma da distribuição de frequêências e seus parâmetros estatísticos (média, variância, coeficiente de variação, assimetria e curtose). A mesma análise foi feita sobre os dados compostos para verificar se a suavização

Departamento de Geologia Econômica e Geofísica Aplicada, Instituto de Geociências, USP. 
introduzida pela composição foi grande ou não. Estas análises feitas na preparação dos dados são úteis na verificação de erros de dados, por simples erros de digitação, os quais podem ser eliminados em tempo, antes dos trabalhos de avaliação de reservas propriamente dita. Finalmente, é apresentado também um estudo de correlação dos teores de cobre e ouro compostos para a altura das bancadas, onde pôde-se verificar a boa correlação existente ente os mesmos e que os teores de cobre são ligeiramente superiores ao de ouro, conforme a reta de regressão obtida. 